\title{
SISTEM INFORMASI PENDAPATAN DAN PENJUALAN PADA PT. WORLD WIDE EQUIPMENT SOUTH EAST ASIA (WWESEA)
}

\author{
Cahyo Budi Santoso \\ Dosen Tetap Prodi Akuntansi Fakultas Ekonomi Universitas Riau Kepulauan
}

\begin{abstract}
The purpose of this study was to determine: 1). Knowing and provide an explanation of the implementation of revenue and sales information system at PT. World Wide Equipment South East Asia (Batam). 2). To determine whether there is influence between information systems and sales revenue with the effectiveness of the company.The results showed the application of information systems and information revenue and sales revenue at PT. World Wide Equipment South East Asia (WWESEA) are adequate and have been qualified and characteristics. Information systems and sales revenue despite the Company is still in the development stage, through the management-level managers below.Results of research on the evaluation of efficiency in project cost control Spudcans Lisa is located on a promontory Singkuang showed favorable revenue and earnings that are not favorable to any such revenues. But in general there is a lucrative income of SGD 1.700 .000 million reduced SGD 1.46495 million multiplied by $100 \%$ of the revenue to the project SPUDCANS LISA SGD 235.050.From these results it can be concluded that the revenue and sales information system at PT. World Wide Equipment South East Asia has been good and adequate. This looks to have fulfilled all the indicators of income and sales information systems. The effectiveness and efficiency of revenue and sales have not fully maximized, because there is a difference masti unfavorable in some jobs that have been planned, although overall has occurred efficient.
\end{abstract}

Keywords : system information, revenue, income

\section{LATAR BELAKANG}

Pada saat ini sistem informasi pendapatan dan penjualan merupakan hal yang sangat penting dalam menjalankan proses bisnis di dalam sustu perusahaan. Untuk itu sistem informasi pendapatan dan penjualan sangat dibutuhkan dalam membantu mengelolah data. Sistem informasi pendapatan dan penjualan tersebut dimaksudkan agar perusahan dapat menjalankan proses pendapatan dan penjualan yang baik. 
Tujuan berdirinya suatu perusahaan adalah untuk memproleh laba yang optimum dalam jangka panjang melalui barang atau jasa yang dihasilkan dan dipasarkan, sehingga memungkinkan dapat dipertahankan eksistensinya dalam masyarakat serta mampu berkompotisi dengan para pesaingnya. Oleh karena itu pimpinan perusahaan harus mampu mengelolah perusahaan secara efesien dan efektuf atau dengan kata lain ,dapat menekan serendah mungkin faktor-faktor yang menghambat operasi perusahaan untuk mencapai tujuanya. Sistem informasi pendapatan dan penjualan dalam suatu organisasi perusahaan disarankan sangatlah penting untuk menunjang tercapainya tujuan perusahaan. Dalam hal ini adalah sistem informasi pendapatan dan penjualan, karena tanpa sistem yang baik tentu akan berakibat fatal bagi financial perusahaan. Agar kegiatan pendapatan dan penjualan dapat berjalan baik, maka diperlukan sistem informasi yang baik pula, dengan harapan sistem informasi pendapatan dan penjualan dapat memberikan informasi yang tepat dan akurat bagi kelancaran operasional perdagangan. Namun, pada kenyataanya, seringkali sistem informasi pendapatan dan penjualan yang berjalan tidak sesuai dengan kebutuhan bahkan menimbulkan masalah yang kompleks bagi perusahaan seperti terjadinya kecurangan baik pada sistem aplikasi maupun informasi dalam perusahaan.

PT. World Wide Equipment South East Asia yang berlokasi ditanjung sinkuang merupakan sala satu perusahaan yang bergerak di bidang produksi barang dan jasa dimana perusahaan tersebut melayani sebagian besar barang-barang produksi yang siap untuk dijual. Pendapatan dan penjualan merupakan proses bisnis yang utama di dalam perusahaan tersebut. Dan menyadari akan pentingnya audit sistem informasi pada perusahaan dengan tujuan untuk mengaktifkan sistem informasi yang berjalan pada proses pendapatan dan penjualan.

Berdasarkan uraian di atas tersebut maka dilakukan evaluasi pengendalian agar sistem informasi pendapatan dan penjualan dalam perusahaan dapat berjalan secara efesien dan efektif mengingat pentingnya pengendalian sistem informasi pendapatan dan penjualan pada PT. World Wide Equipment South East Asia dalam proses penjualan maka dipilih evaluasi pengendalian sistem informasi pendapatan dan penjualan pada PT.World Wide Equipment South East Asia sebagai topik penelitian.

\section{Rumusan Masalah}

Untuk mengarahkan penyusunan dan penulisan skripsi ini, penulis membatasi rumusan masalah penelitian sebagai berikut:

1. Dalam melakukan evaluasi, penulis hanya terfokus pada sistem informasi pendapatan dan penjualan yang digunakan pada PT.World Wide Equipment South East Asia.

2. Dalam melakukan evaluasi, apakah ada pengaruh antara sistem informasi pendapatan dan penjualan dengan evektifitas perusahaan. 


\section{Tujuan dan Manfaat}

1. Mengevaluasi penerapan sistem informasi pendapatan dan penjualan pada proses bisnis perusahaan yang sedang berjalan.

2. Mengidentifikasi permasalahan sistem informasi pendapatan dan penjualan pada PT. World Wide Equipment South East Asia.

Manfaat yang akan diterimah dari penulis ini adalah:

1. Menambah wawasan mengenai sistem informasi pendapatan dan penjualan

2. Membantu perusahaan dalam mengefektifan sistem informasi pendapatan dan penjualan.

\section{TINJAUAN PUSTAKA}

\section{Sistem Informasi Pendapatan dan Penjualan}

Tinjauan umum tentang sistem informasi pendapatan dan penjualan adalah untuk memberitahukan atau menginformasikan kepada suatu lembaga, masyarakat, atau pelanggan tentang bagaimana cara kita dalam mendapatkan hasil dari penjualan yang maksimal tanpa mengalami kerugian sedikitpun.

\section{Pengertian Sistem}

Sistem adalah sekelompok unsur yang erat berhubungan satu dengan lainnya, yang berfungsi bersama-sama untuk mencapai tujuan tertentu (Mulyadi, 2001). Sistem juga adalah kumpulan dari komponen-komponen peralatan model requirements, function dan interface (Mathiassen, Lars, 2000). Sistem adalah sekelompok elemen yang terintegrasi dengan maksud yang sama untuk mencapai suatu tujuan. Sistem adalah sekumpulan komponen yang saling bekerjasama untuk mencapai tujuan guna memperbaiki organisasi ke arah yang lebih baik (Mcleod 1998) Suatu sistem terdiri dari sejumlah komponen yang saling berinteraksi, yang artinya saling bekerja sama membentuk suatu kesatuan. Komponen-komponen sistem dapat berupa suatu suatu subsistem atau bagian-bagian sistem. Suatu sistem tidak peduli betapapun kecilnya, selalu mengandung komponen atau subsistem. Suatu sistem mempunyai karakteristik atau sifat-sifat yang tertentu, yaitu mempunyai komponenkomponen, batas sistem, lingkungan luar sistem, penghubung, masukan, keluaran dan sasaran tujuan. Elemen-elemen sebuah

sistem menurut James Hall ( 2001 : 5 ) "sebuah sistem adalah sekelompok atau lebih komponen-komponen yang saling berkaitan (interralated) atau subsistem-subsistem yang bersatu untuk mencapai tujuan yang sama (common purpose)."

\section{Pengertian Informasi}

Informasi berarti hasil suatu proses yang terorganisasi, memiliki arti dan bagi orang yang menerimanya. Ada kalanya dibedakan antara data dan informasi. Data berarti fakta acak yang diterima sebagai masukan atau input pada suatu sistem informasi. Data biasanya menunjukkan suatu observasi atau penguluran terhadap suatu 
kegiatan yang penting bagi suatu sistem informasi. Data yang sudah diproses menjadi informasi digunakan oleh pengambil keputusan untuk membuat keputusan yang lebih baik.

Berkembangnya kebutuhan informasi telah mendorong perkembangan akuntansi sebagai suatu sistem informasi. Perkembangan ini mengakibatkan perubahan beberapa istilah dan teknik yang digunakan. Jika sebelumnya pemrosesan data akuntansi disebut dengan sistem akuntansi, maka sekarang relevan dengan sebutan Sistem Informasi Akuntansi. Perubahan ini berkaitan erat dengan penerapan teknologi pengolahan data yang lebih efisien dan dapat mengolah informasi yang lebih banyak. Perkembangan teknologi komputer sangat mempengaruhi perubahan cara kerja akuntansi dalam mengolah transaksi menjadi informasi. Pada masa sekarang ini sistem informasi yang didasarkan pada komputer dikenal dengan istilah sistem informasi akuntansi.

\section{Pengertian Pendapatan}

Tujuan pokok dijalankannya suatu usaha perdagangan adalah untuk memperoleh pendapatan, dimana pendapatan tersebut dapat digunakan untuk memenuhi kebutuhan hidup dan kelangsungan hidup usaha perdagangannya. Pendapatan yang diterima adalah dalam bentuk uang, dimana uang adalah merupakan Alat pembayaran atau alat pertukaran.

Selanjutnya, pendapatan juga dapat di definisikan sebagai jumlah seluruh uang yang diterima oleh seseorang atau rumah tangga selama jangka waktu tertentu. (biasanya satu tahun), pendapatan terdiri dari upah, atau penerimaan tenaga kerja, pendapatan dari kekayaan seperti sewa, bunga dan deviden, serta pembayaran transfer atau penerimaan dari pemerintah seperti tujangan sosial atau asuransi pengangguran. Adapun menurut Lipsey pendapatan terbagi dua macam, yaitu pendapatan perorangan dan pendapatan disposable. Pendapatan perorangan adalah pendapatan yang dihasilkan oleh atau dibayarkan kepada perorangan sebelum dikurangi dengan pajak penghasilan perorangan. Sebagian dari pendapatan perorangan dibayarkan untuk pajak, sebagian ditabung oleh rumah tangga ; yaitu pendapatan perorangan dikurangi dengan pajak penghasilan. Pendapatan disposible merupakan jumlah pendapatan saat ini yang dapat di belanjakan atau ditabung oleh rumah tangga; yaitu pendapatan perorangan dikurangi dengan pajak penghasilan. Sedangkan pendapatan atau penghasilan adalah sebagai balas karya. Pendapatan sebagai balas karya terbagi dalam enam kategori, yaitu upah/gaji yang merupakan balas jasa untuk pekerjaan yang dilaksanakan dalam hubungan kerja dengan orang/instansi lain (sebagai karyawan yang dibayar), laba usaha sendiri yaitu balas karya untuk pekerjaan yang dilakukan sebagai pengusaha yang mengorganisir produksi, mengambil keputusan tentang kombinasi faktor produksi serta menanggung resikonya sendiri entah sebagai petani/ tukang/pedagang dan sebagainya, laba perusahaan (perseroan) atau laba yang diterima atau diperoleh perusahaan yang berbentuk atau badan hokum, sewa atas jasa yang diterima oleh pemilik atas penggunaan hartanya seperti tanah, rumah atau barang-barang tahan lama, penghasilan campuran yaitu penghasilan yang diperoleh dari usaha seperti ; petani, tukang, warungan, pengusaha kecil, dan sebagainya disebut bukan laba, melainkan terdiri dari berbagai kombinasi unsur-unsur pendapatan, serta bunga atau balas jasa untuk pemakaian faktor produksi uang yang diterima oleh seseorang dan perusahaan 
dalam bentuk gaji, upah, sewa, bunga, laba, dan lain sebagainya bersama-sama dengan tunjangan pengangguran, uang pensiun, dan lain sebagainya.

\section{Pengertian Sistem Informasi Penjualan}

Sistem informasi penjualan adalah sub system informasi bisnis yang mencakup kumpulan prosedur yang melaksanakan, mencatat, mengkalkulasi, membuat dokumen dan informasi penjualan untuk keperluan manajemen dan bagian lain yang berkepentingan, mulai dari diterimanya order penjualan sampai mencatat timbulnya tagihan/piutang dagang.

\section{Komponen umum Sistem Informasi Pendapatan dan Penjualan}

\section{Pengertian Pendapatan}

Pendapatan adalah sesuatu yang sangat penting dalam setiap perusahaan.Tanpa ada pendapatan mustahil akan didapat penghasilan atau earnings.Pendapatan adalah penghasilan yang timbul dari aktivitas perusahaan yangbiasa dikenal atau disebut penjualan, penghasilan jasa(fees), bunga, dividen, royalti dan sewa.

\section{Pengakuan Pendapatan Secara Umum}

Pendapatan merupakan salah satu komponen penting laporan keuangan. Namun permasalahan utama dalam akuntansi untuk pendapatan adalah menentukan saat pengakuan pendapatan dalam Statement of Finansial.

\section{Pengukuran Pendapatan}

Pendapatan harus diukur dengan nilai wajar imbalan yang diterima atau yang dapat diterima.Jumlah pendapatan yang timbul dari suatu transaksi biasanya ditentukan oleh persetujuan antara perusahaan dan pembeli atau pemakai aktiva tersebut. Jumlah tersebut diukur dengan nilai wajar imbalan yang diterima atau yang dapat diterima perusahaan dikurangi jumlah diskon barang yang diperbolehkan oleh perusahaan. Pada umumnya, imbalan tersebut berbentuk kas atau setara kas yang diterima atau dapat diterima. Namun, bila arus masuk dari kas atau setara kas ditangguhkan nilai wajar dari imbalan tersebut mungkin kurang dari jumlah nominal dari kas yang dapat diterima.

Metode Penjualan Cicilan

Menurut metode ini, pendapatan lebih baik diakui ketika kas diterima dari pada saat penjualan. Penerapan yang paling umum untuk metode ini adalah: (a) Untuk barang dagangan laba akan diakui sebesar persentase laba (laba dibagi penjualan)dikalikan penerimaan cicilan; (b) Untuk real estate dengan rumusan yang sama dengan barang dagangan,maka rumusan untuk mencari laba yang direalisasi juga dapat diterapkan pada perusahaan real estate, hanya terdapat beberapa perbedaan dalam jurnalnya. Hal ini dikarenakan karakteristik perusahaanreal estate berbeda dengan perusahaan dagang. 3. Metode Perolehan Kembali Harga Pokok (Cost Recovery Method ). Menurut metode ini, tidak ada laba yang diakui untuk suatu penjualansampai harga pokok barang yang dijual diperoleh kembali melalui penerimaan kas. Setelah itu, semua penerimaan berikutnya dilaporkan sebagai pendapatan. Metode ini hanya digunakan apabila 
keadaan-keadaan yang melingkupi suatu penjualan sangat tidak pasti sehingga pengakuan yang lebih awal tidak mungkin dilakukan.

Metode Reduced Profit

Kriteria yang harus dipenuhi apabila suatu perusahaan ingin menerapkan metode ini, yaitu:

Apabila pembayaran awal yang disyaratkan telah terpenuhi.b. Pembayaran tiap tahun harus mencakup amortisasi bunga dan hutang pokok dari pinjaman maksimal penjual yang dapat diperoleh untuk properti tersebut.Kriteria ini tidak dapat diterapkan di Indonesia, sebab tidak ada yang mengatur besarnya pinjaman maksimal yang dapat diberikan perusahaan untuk pembiayaan suatu properti. Metode ini mengakui lab pada saat penjualan sebesar laba kotor yang telah dikurangkan dengan selisih antara nominal piutang dengan nilai sekarang anuitas.

Metode kas

Menurut metode ini, semua biaya dibebankan sebagai beban (expense) ketika dikeluarkan dan pendapatan diakui ketika penerimaan kas dilakukan. Metode pengakuan pendapatan dan biaya yang ekstrim ini hanya akan tepat bila tingkat kepastian dari kerugian potensial atas suatu kontrak tidak dapat ditaksir. Metode ini, jarang digunakan dalam penjualan barang dagangan dan real estate karena hak untuk mengambil kembali akan memberikan nilai yang sangat besar bagi penjual.

Metode Akuntansi

Sebelum Pengakuan Pendapatan Perjanjian-perjanjian penjualan tertentu adakalanya melibatkan suatu pertukaran baik barang-barang atau aktiva moneter seperti kas atau wesel tagih sebelum batas dimana proses pendapatan diselesaikan secukupnya untuk mengakui pendapatan. Dalam keadaan seperti ini, prosedur akuntansi yang khusus harus diterapkan.

Adapun metode-metode pengakuan pendapatan yang digunakan adalah:

(1) Metode deposit metode ini menerapkan bahwa tidak ada pendapatan yang diakui sampai kontrak penjualan diselesaikan. Adakalanya uang pembayaran pertama kurang memadai pembayarannya. Apabila uang muka terlalu kecil, kepastian transaksi diragukan. Kas yang berasal dari setoran pembelian dilaporkan sebagai deposito (uang muka atau tanda jadi) atas kontrak dan dalam neraca digolongkan sebagai hutang. Aktiva tetap yang akan dijual tetap ditunjukan sebagai harta penjual dan hutang yang berhubungan dengan aktiva itu tetap dilaporkan sebagai hutang penjual. Jika pembeli membatalkan niatnya dan uang muka atau deposito itu menjadi milik penjual (sebagai denda), maka, deposito itu harus dikredit sebagai laba. (2) Metode Penjualan Konsinyasi (Consigment Method) Metode ini digunakan hanya apabila consignor (penjual) menitipkan barang dagangan kepada pihak lain,yaitu: consignee, yang kemudian bertindak sebagai agen bagi consignor untuk menjual barang-barang tersebut. Perlakuan akuntansinya, hak milik dari barang dagangan tersebut tetap dikuasai olehconsignor sampai suatu penjualan dilaksanakan.Consignor harus membuat catatan akuntansi khusus,seperti perkiraan-perkiraan 'persediaan dalam 
konsinyasi' yang terdiri dari barang yang dititipkan keconsignee dan biaya-biaya yang dikeluarkan yang berhubungan dengan barang konsinyasi tersebut.Consignee biasanya membuat catatan pro-memori atas penerimaan persediaan untuk kepentingan pengendalian. Dan biaya yang berhubungan dengan barang konsinyasi yang telah dikeluarkan olehconsignee, dicatat pada perkiraan piutang.Consignee juga berhak atas komisi jika penjualan dilaksanakan dengan sukses.Apabila suatu penjualan dilaksanakan, consignor akan mengakui penjualan itu sebagai pendapatan sesuai dengan salah satu dari metode-metode pengakuan pendapatan, dan consigne akan mengakui komisi sebagai pendapatan dari transaksi tersebut.

\section{Fungsi sistem informasi pendapan dan penjualan}

Fungsi utama sistem informasi pendapatan dan penjualan adalah mendorong seoptimal mungkin agar dapat menghasilkan berbagai informasi pendapatan dan penjualan yang terstruktur dan berkualitas, yaitu tepat waktu, relevan, dan dapat dipercaya yang secara keseluruhan sistem informasi pendapatan dan penjualan tersebut mengandung arti dan berguna bagi para pelanggan. Sistem informasi pendapatan dan penjualan yang dihasilkan berasal dari pengolahan atas data yang terstruktur, yaitu data yang memenuhi fungsi keabsahan yang telah melalui prosedur pembuatan dan pengumpulan data yang benar, dan keabsahan materil dalam arti data tersebut telah mewakili suatu transaksi keuangan yang terjadi dan benar.mendefinisikan sistem informasi pendapatan dan penjualan sebagai berikut: Merupakan sistem informasi yang sangat penting yang harus didesain dalam perusahaan, hal ini disebabkan oleh karena penjualan, baik penjualan secara kredit maupun penjualan secara tunai merupakan sumber pendapatan perusahan.Dari definisi di atas yang dimaksud sistem informasi pendapatan dan penjualan adalah seperangkat sumber daya dan modal dalam suatu organisasi yang dibangun untuk menyajikan informasi yang akan diperoleh dari pengumpulan dan pemerosesan data-data yang saling berhubungan, dan dioperasikan secara bersama-sama untuk melaksanakan aktivitas utama suatu organisasi perusahaan, sehingga perusahaan dapat mencapai tujuan yang ditetapkan.

\section{Manfaat dan Tujuan Sistem Informasi pendapatan dan penjualan}

Sistem informasi dibuat dan dibangun dengan baik agar meningkatkan produktivitas, menghilangkan kegiatan yang tidak memiliki manfaat, meningkatkan layanan, mengkoordinasikan setiap bagian dalam perusahaan serta meningkatkan kualitas kebijakan dalam manajemen.Sedangkan secara umum manfaat Sistem Informasi dapat dikategorikan dengan manfaat berwujud (tangible benefit) dan manfaat tak berwujud (intangible benefit). Berikut saya membahas sedikit tentang manfaat berwujud (tangible benefit) dan manfaat tak berwujud (intangible benefit).

\section{MATODOLOGI PENELITIAN}

\section{Tempat Penelitian}


Penelitian ini dilakukan pada tahun 2013 dan tempat penelitian PT.World Wide Equipment South East Asia yang berlokasi di Tanjung Sinkuang Batam Indonesia.

\section{Sumber Data}

Sumber data yang dikumpulkan bersifat data sekunder.

Menurut (Dr. Indrianto, Nur, M. SC. 147) data sekunder adalah' penelitian arsip (archival research) yang memuat kejadian masa lalu (historis).' 'Data sekunder adalah sumber data penelitian yang diperoleh peneliti secara tidak langsung melalui media perantara. Data sekunder berupa bentuk laporan atau publikasi yang disebut juga data eksternal yang datangnya dari luar perusahaan seperti buku teks dan catatan dan laporan historis yang telah disusun dalam arsip (data dekomenter).

\section{Jenis Penelitian}

Penelitian ini dilaksanakan dengan metode deskriptif, yaitu penelitian yang dilaksanakan untuk melakukan pengujian terhadap fenomena atau kejadian.

Menurut Prof.Dr Sugiyono (2009.1) metode deskriptif kualitatif adalah kegiatan yang meliputi pengumpulan data dalam rangka menguji dan menjadwal atas pertanyaan yang menyangkut keadaan pada waktu yang sedang berjalan dari pokok suatu penelitian.

\section{HASIL PENELITIAN DAN PEMBAHASAN}

Produk yang dihasilkan oleh PT WWE SEA Batam adalah berupa jasa dan barang jadi. Jasa dapat berupa penyewaan alat berat dan alat- alat kerja lainnya dan manpower, dan repair alat berat. Untuk barang jadi dapat berupa steel fabrication.

Untuk pemasaran sendiri PT WWE SEA Batam sudah mempunyai client atau perusahaan yang selalu menggunakan jasa dari perusahaan ini. PT WWE SEA Batam pemasaran produknya sudah mencapai taraf Internasional. Banyak project-project yang telah diselesaikan atau yang sedang dilaksanakan oleh perusahaan ini.

Berikut adalah penjabaran atas contoh kasus dari sistem informasi pendapatan dan penjualan barang atau jasa pada PT.World Wide Equipment South East AsiaBatam.

Pada tanggal 1 Januari 20134 unit SPUDCANS LISA proyek HAPO 357 dan berat 74,1 ton. Dengan demikian pihak PT World Wide Equipment South East Asia melakukan order barang kepada supplier barang atau material tersebut dengan rincian; 4 unit SPUDCANS LISA proyek HAPO 357 dengan berat 74,1 ton. Kondisi ini digambarkan pada tabel 5.1 . 
Pada saat itu belum terjadi trangsaksi pembelian dan penjualan barang atau material di PT World Wide Equipment South East Asia, sehingga tidak ada perubahan pada jumlah barang atau material yang tersediah. Namun di dalamnya tercantum jumlah satuan atas barang-barang atau material tersebut memanandakan adanya order barang atau material dari supplier barang tersebut. Namun barang yang di order belum datang.

Tanggal 5 maret 2013 barang-barang yang di order datang sesuai dengan pesanan yaitu 4 unit SPUDCANS LISA proyek HAPO 357 sebesar Rp 1,700,000.pihak PT. World Wide Equipment South East Asia langsung melakukan pencatatan atas pembelian barang atau material dengan memasukanya stock barang pada STI. Selain itu, dari PT World Wide Equipment South East Asia juga mencamtumkan nilai HPP dan harga jual barang atau material dalam STI.

$\begin{array}{llll}\begin{array}{l}\text { Project } \\ \text { Name }\end{array} & \text { :SPUDCANS LISA } & \begin{array}{l}\text { Total Steel } \\ (\text { Ton) }\end{array} & : 74.1 \\ \text { Project \# } & : \text { HAPO 357 } & \begin{array}{l}\text { Primary Steel } \\ \text { (Ton) }\end{array} & : 50.6 \\ \text { Client } & : \text { HAPO International Barges B.V } & \text { Sec. Steel (Ton) } & : 23.5 \\ \text { Start Date } & : \text { 1 JANUARI 2013 } & \text { Week\# } & : 5 \\ \text { Duration } & :- & \text { Report Date } & : 5 \text { MEI } 2013 \\ \begin{array}{l}\text { Project } \\ \text { Value (SGD) }\end{array} & \mathbf{1 , 7 0 0 , 0 0 0} & \text { Total Expenses } & \mathbf{1 , 4 6 4 , 9 5 0} \\ \begin{array}{l}\text { Budget } \\ \text { (SGD) }\end{array} & & \text { SGD } & \\ & & \text { Work Progress } & : 100 \%\end{array}$




\section{KESIMPULAN DAN SARAN}

\section{Kesimpulan}

Berdasarkan uraian dan interprestasi di atas mengenai sistem informasi pendapatan dan penjualan pada PT.World Wide Equipment South East Asia sudah baik dan memadai. Hal ini telah terlihat terpenuhunya semua indikator dari sistem informasi pendapatan dan penjualan.

Efektifitas dan efesiensi pendapatan dan penjualan belum sepenuhnya maksimal, karena masih terdapat selisih yang tidak menguntungkan pada beberapa pekerjaan yang telah direncanakan meskipun secara keseluruhan sudah terjadi efesiensi.

\section{Saran}

Meskipun sistem informasi pendapatan dan penjualan sudah sesuai namun perlu dilakukan pemantapan pada efektifitas dan efesiensi terhadap sistem informasi pendapatan dan penjualan agar tidak ada pekerjaan-pekerjaan yang terdapat selisih yang tidak menguntungkan.

\section{DAFTAR PUSTAKA}

AI. Haryono Jusup. Dasar-dasar Akuntansi Edisi 6. Yogyakarta: Bagian Penerbit Sekolah Tinggi IImu Ekonomi YKPN, 2003.

Hansen, Don R., Marianne M. Mowen. Cost Management: Accounting and Control. Ohio: South-Wertern College Publishing, 1995.

Ikatan Akuntan Indonesia, Standar Akuntansi Keuangan. Jakarta: selemba Empat,2007.

Kieso, Donald E., Jerry J. Weygant. Intermediate Accounting Edition. New York: John Wiley, Sons,lnc., 1998.

Thacker, Ronald J. Accouting Principles 2 Edition. Englewood Cliffs, New Jersey: PrenticeHall, lnc.,1979.

Warren, Karl S., James M. Reeve, Philip E. Fess. Accounting 20 Edition. United States: Thomson Learnig, lnc., 2002.

Weygandt, Jeffry j., Donald E. Kieso, Walter G. Kell. Accounting Principles 4 Edition. New Yotk: John wiley Sons, lnc., 1996. 